\title{
Familial Gynecomastia with Increased Extraglandular Aromatization of Plasma Carbon ${ }_{19}$-Steroids
}

\author{
G. D. Berkovitz, A. Guerami, T. R. Brown, P. C. MacDonald, and C. J. Migeon \\ Division of Pediatric Endocrinology, The Johns Hopkins Hospital and School of Medicine, Baltimore, Maryland 21205; Cecil H and \\ Ida Green Center for Reproductive Biology Science and the Departments of Biochemistry and Obstetrics and Gynecology, \\ The University of Texas Southwestern Medical School, Dallas, Texas 75235
}

\begin{abstract}
We evaluated a family in which gynecomastia occurred in five males in two generations. In each affected subject, gynecomastia and male sexual maturation began at an early age. The ratio of the concentration of plasma estradiol-17 $\beta$ to that of plasma testosterone was elevated in each affected subject. In the three siblings with gynecomastia, the transfer constant of conversion of androstenedione to estrone (i.e., the fraction of plasma androstenedione that was converted to estrone as measured in the urine) was 10 times that of normal persons. The transfer constant of conversion of testosterone to estradiol-17 $\beta$ in the one subject studied also was 8-10 times that of normal men, whereas the transfer constants of conversion of estrone to estradiol-17 $\beta$ and of estradiol-17 $\beta$ to estrone were normal. Despite the elevation in extraglandular aromatase activity, there was a normal response of the hypothalamic-pituitary axis to provocative stimuli. This is the second documentation of gynecomastia that is associated with increased extraglandular aromatase activity, and the first time that the defect was found to be familial with a probable $\mathrm{X}$-linked (or autosomal dominant, sex limited) mode of inheritance.
\end{abstract}

\section{Introduction}

Gynecomastia is a common finding among pubertal boys; usually, it is limited to a nodule of subareolar tissue, and ordinarily the breast enlargement begins during the early stages of the pubertal process and thereafter regresses within 6-18 mo. Levels of plasma testosterone $(T){ }^{1}$ estradiol-17 $\beta\left(E_{2}\right)$, serum luteinizing hormone (LH), and follicle-stimulating hormone (FSH) in boys with pubertal gynecomastia are not significantly different from those in unaffected boys (1), although a relative increase in the level of plasma $E_{2}$ compared with that of $T$ during certain times of the day has been found (2).

In a small percentage of apparently normal pubertal boys,

Received for publication 23 April 1984 and in revised form 11 February 1985.

1. Abbreviations used in this paper: $\mathrm{A}$, androstenedione; DHA, dehydroepiandrosterone; $E_{1}$, estrone; $E_{2}$, estradiol-17 $\beta$; FSH, follicle-stimulating hormone; hCG, human chorionic gonadotropin; LH, luteinizing hormone; LHRH, LH-releasing hormone; $\mathrm{P}$, progesterone; $[\rho]_{\mathrm{BU}}{ }^{\mathrm{AEI}}$, plasma $A$ to estrone; $[\rho]_{\mathrm{BU}}^{\mathrm{TE} 2}$, plasma $\mathrm{T}$ to $\mathrm{E}_{2} ;[\rho]_{\mathrm{BU}}{ }^{\mathrm{EIE} 2}$, plasma $\mathrm{E}_{1}$ to $E_{2} ; P R-E_{1}$, production rate $E_{1} ; P R-E_{2}$, production rate $E_{2} ; T$, testosterone; TRH, thyrotropin-releasing hormone; TSH, thyroid-stimulating hormone.

J. Clin. Invest.

(c) The American Society for Clinical Investigation, Inc.

$0021-9738 / 85 / 06 / 1763 / 07 \$ 1.00$

Volume 75, June 1985, 1763-1769 persistent and marked gynecomastia develops even though the plasma levels of $T, E_{2}$, prolactin, gonadotropins, and testosterone-estradiol binding globulin in such subjects are normal at the time of evaluation (3). Marked and persistent breast enlargement, however, can sometimes be associated with Klinefelter syndrome or an underlying abnormality in male sexual differentiation $(4,5)$, including partial gonadal dysgenesis or various forms of androgen resistance. In 1977, Hemsell et al. (6) reported the findings in a prepubertal boy who developed gynecomastia as a consequence of extraordinarily high extraglandular aromatization of plasma androstenedione (A) and T. This was the first report of such a metabolic abnormality, and to the best of our knowledge no other affected subjects have been described since. In that study, a family history was not available since the affected boy was an adopted child (MacDonald, P. C., personal communication). Recently, we evaluated a family in which marked gynecomastia developed in three brothers, a maternal cousin, and a maternal uncle. The gynecomastia was unusual in several respects: $(a)$ it began at an early age; $(b)$ from initial studies of plasma steroids, we found that there was an elevation in the ratio of plasma $E_{2} / T$; (c) known causes of gynecomastia were excluded in all subjects; and $(d)$ in studies of extraglandular aromatization of plasma $\mathrm{C}_{19}$-steroids, it was found that the fractional conversion of plasma $A$ to estrone $\left(E_{1}\right),[\rho]_{B U}{ }^{A E 1}$, was 10 times greater than normal in three subjects studied; and, similarly, the fractional conversion of plasma $T$ to $E_{2},[\rho]_{\mathrm{BU}}{ }^{\mathrm{TE} 2}$, in the only subject studied, was also 8-10 times that found in normal men. Despite the excessive peripheral aromatase activity, there was evidence of normal gonadotropin release by the pituitary and normal Leydig cell function in the affected subjects.

\section{Case histories}

The pedigree of a family in which there was marked and persistent gynecomastia in three siblings, a maternal cousin, and a maternal uncle is presented in Fig. 1. In each of the affected subjects, gynecomastia began at the time of other pubertal changes between 10 and 11 yr of age. Breast enlargement progressed steadily, although there was a slow progression in the maturational events of male puberty. In all five subjects, there was a normal 46,XY karyotype. Thyroid and liver function tests as well as serum levels of prolactin were normal in all five subjects (data not shown). There was one additional adult male (subject II-6) in the second generation who did not have gynecomastia. His two sons were 10 and $5 \mathrm{yr}$ of age at the commencement of these studies.

Subjects III-3. At the time of initial evaluation, the proband (subject III-3) was 11-11/12 yr old. The early medical history of this boy was unremarkable. Pubic hair and breast development began concomitantly when the boy was 10 -yr-old. Height was $156.7 \mathrm{~cm}$ (75th percentile) and weight was $63 \mathrm{~kg}$ (>95th percentile). Bone age was $14-6 / 12$ yr ( $>2$ SD above the mean 


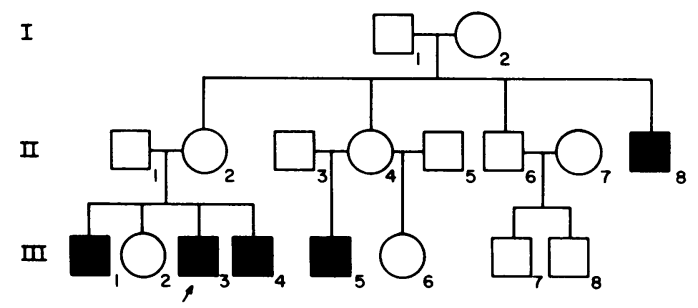

Figure 1. Pedigree of a kindred with familial gynecomastia.

for age); and, a female fat distribution (Fig. 2) and $18 \times 14-$ $\mathrm{cm}$ breasts were present. Pubic hair growth and distribution were that of Tanner Stage III (7) and the stretched penile length was $8.5 \mathrm{~cm}$. The testes were $1.5 \times 3 \mathrm{~cm}$ bilaterally, with normal contour. Values for plasma $T$ and $E_{2}$, and for serum LH and FSH are given in Table I. In Table II, we present the changes in pubertal development and plasma steroids and gonadotropin levels over the course of $1 \mathrm{yr}$. Plasma $T$ remained somewhat low for the stage of sexual development, whereas the ratio of plasm $E_{2} / T$ was elevated consistently. An $\mathrm{X}$ ray of the skull was normal, as was a CT scan of the adrenal glands.

Subject III-1. The older sibling of the proband was 16-5/ 12-yr-old at the time of initial evaluation. Height was 175.8 $\mathrm{cm}$ (50th percentile), weight was $60.8 \mathrm{~kg}$ (50th percentile), and the bone age was normal. Except for gynecomastia, there was a normal male body habitus. The breast tissue was $4 \times 4 \mathrm{~cm}$ on the right and $6 \times 6$ on the left. Pubic hair distribution was that of Tanner Stage IV and the penile length was $11 \mathrm{~cm}$. The values for plasma steroids and gonadotropins at the time of the initial visit are given in Table $\mathrm{I}$; and, the results of similar measurements over the next 12 mo of observation are given in Table II. Plasma levels of $\mathrm{T}$ and $\mathrm{A}$ in this subject were normal for the stage of sexual development.

Subject III-4. During the course of the study, the younger sibling of the proband developed unilateral gynecomastia (at $10-8 / 12 \mathrm{yr}$ of age). Height was $146 \mathrm{~cm}$ (75th percentile) and weight was $38 \mathrm{~kg}$ (50th percentile). Physical examination was normal except for the presence of $4.5 \times 4.5 \mathrm{~cm}$ of breast tissue on the left breast. There was a scant amount of pubic hair; the penile length was $8.5 \mathrm{~cm}$ and the testes were $1 \times 2.5 \mathrm{~cm}$ bilaterally. The results of his endocrine evaluation are given in Table I. In this boy, bone age, determined when he was 11$5 / 12 \mathrm{yr}$ of age, was 13-6/12 yr, a value $>2$ SD above the mean for that age.

Subject III-5. A maternal cousin of the proband was $15 \mathrm{yr}$ of age when he was first evaluated by us. Breast tissue, which was noted first at $11 \mathrm{yr}$ of age, increased steadily in size, and bilateral mastectomy was performed at $12 \mathrm{yr}$ of age. When he was 15 -yr-old, height was $179 \mathrm{~cm}$ (90th percentile) and weight was $61 \mathrm{~kg}$ (50th percentile); at this time, there was a normal male body habitus. Pubic hair distribution was that of Tanner Stage $\mathrm{V}$ and the stretched penile length was $11 \mathrm{~cm}$. Testes were $2 \times 4.5 \mathrm{~cm}$. The plasma level of T, given in Table I, was normal for that age, but the plasma level of $E_{2}$ was elevated. The plasma level of DHA-sulfate $(221 \mu \mathrm{g} / \mathrm{dl})$ was normal.
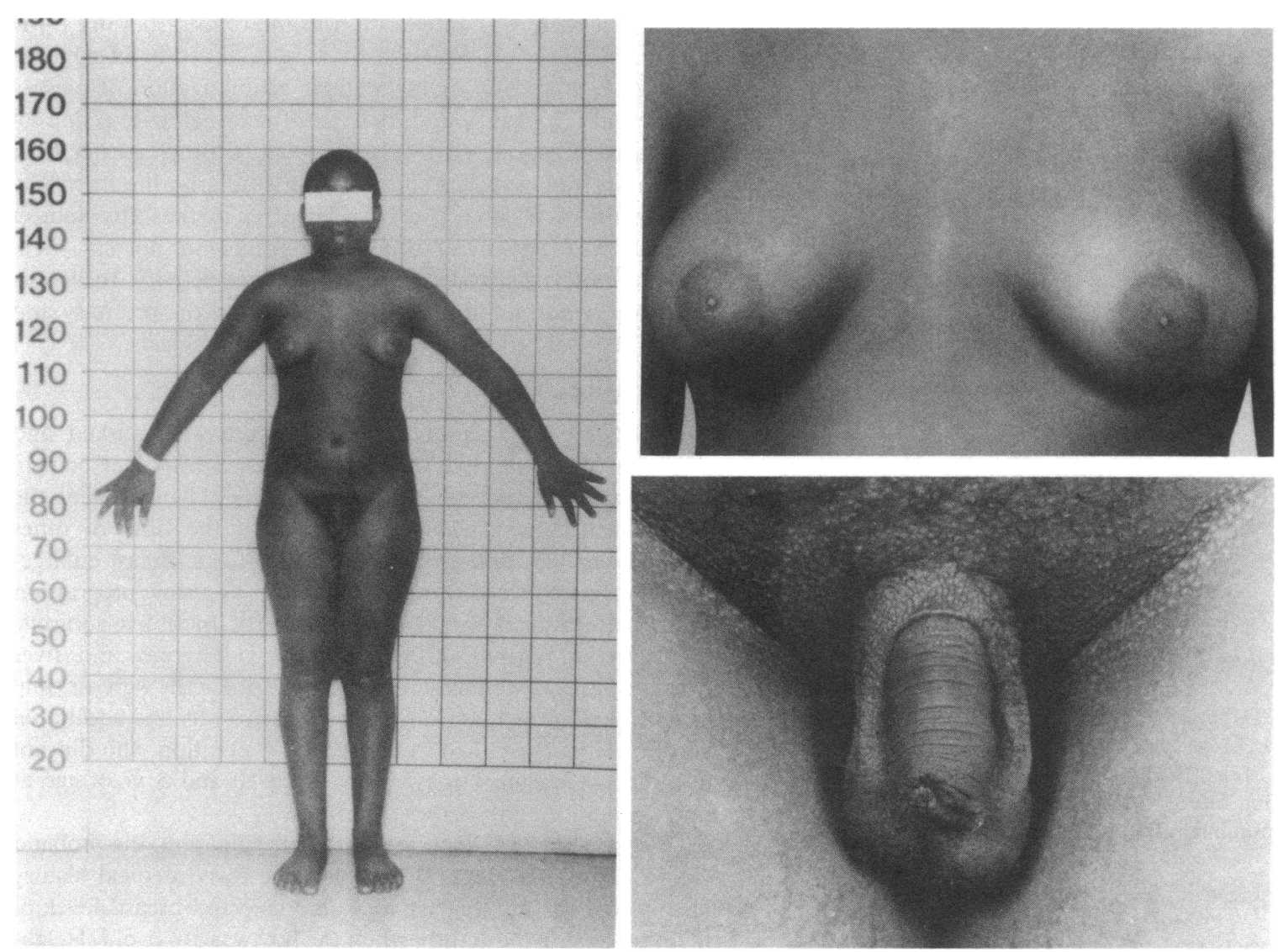

Figure 2. Subject III-3 at age 11-11/12 yr; breast development present since $10 \mathrm{yr}$ of age. Breasts were $18 \times 14 \mathrm{~cm}$ and pubic hair distribution was Tanner Stage III. 
Table I. Hormonal Evaluation of Subjects with Familial Gynecomastia

\begin{tabular}{lllllll}
\hline Subjects & Age & Tanner stage & T & E & LH & FSH \\
\hline & $y r$ & & $n g / d l$ & $n g / d l$ & $n g / m l$ & $n g / m l$ \\
Brother III-1 & $16-5 / 12$ & IV & 58 & 3.6 & 58 & 314 \\
Proband III-3 & $11-11 / 12$ & III & 32 & 6.2 & 35 & 131 \\
Brother III-4 & $10-8 / 12$ & II & 13 & 2.8 & 19 & 107 \\
Maternal uncle II-8 & 29 & V & 506 & 9.8 & 38 & 109 \\
Maternal cousin III-5 & 15 & V & 342 & 6.2 & 30 & 71 \\
Normal adult men (mean \pm SD or range) & & $575 \pm 150$ & $1-6$ & $50 \pm 14$ & $187 \pm 89$ \\
\hline
\end{tabular}

Subject II-8. The maternal uncle of the proband first noted gynecomastia when he was $10 \mathrm{yr}$ of age and the breast tissue was removed surgically at 12 yr of age. When evaluated by us for the first time, he was a moderately obese 29-yr-old man with fat distribution of a woman. Height was $160 \mathrm{~cm}(<5$ th percentile) and weight was $77 \mathrm{~kg}$ ( $>90$ th percentile). Pubic hair distribution was that of Tanner Stage $V$. The penile length was $11.5 \mathrm{~cm}$ and the testes were $2 \times 4 \mathrm{~cm}$ bilaterally. As given in Table $I$, the plasma level of $E_{2}$ in this subject was elevated, although the plasma $T$ was normal.

\section{Methods}

Preparation of radiolabeled steroids for intravenous infusion. $\left[4-{ }^{14} \mathrm{C}\right] \mathrm{A}$ $(57.4 \mathrm{mCi} / \mathrm{mmol}),\left[6,7-{ }^{3} \mathrm{H}\right] \mathrm{E}_{1}(60 \mathrm{Ci} / \mathrm{mmol}),\left[4{ }^{14} \mathrm{C}\right] \mathrm{T}(51.9 \mathrm{mCi} /$ $\mathrm{mmol}),\left[6,7-{ }^{3} \mathrm{H}\right] \mathrm{E}_{2}(53 \mathrm{Ci} / \mathrm{mmol})$, and $\left[4{ }^{14} \mathrm{C}\right] \mathrm{E}_{2}(57.0 \mathrm{mCi} / \mathrm{mmol})$ were obtained from New England Nuclear, Boston, MA. All radiolabeled steroids were purified by paper chromatography and passage through a 0.2- $\mu \mathrm{m}$ Millex-FG filter unit (Millipore Corp., Bedford, MA). Before use, an aliquot of the material was removed for bacteriologic culture and determination of pyrogenicity.

Production rate of estrone ( $\left.P R-E_{\nu}\right)$ and transfer constant of conversion of $[\rho]_{B U}{ }^{A E I}$. These studies were conducted in subjects III-1, III-3, and III-4 at ages 17-2/12, 12-2/12, and 11-1/12 yr, respectively. Subject III-3 was given $12.4 \mu \mathrm{Ci}\left[{ }^{14} \mathrm{C}\right] \mathrm{A}$ and $5.68 \mu \mathrm{Ci}\left[{ }^{3} \mathrm{H}\right] \mathrm{E}_{1}$ dissolved in 112 $\mathrm{ml}$ of ethanol $(6 \%)$ in normal saline, one-sixth of it being infused as a bolus intravenously, and the remainder being delivered as a constant intravenous infusion over $10 \mathrm{~h}$ by a Harvard pump. Subject III-1 was given $5.02 \mu \mathrm{Ci}\left[{ }^{14} \mathrm{C}\right] \mathrm{A}$ and $2.71 \mu \mathrm{Ci}\left[{ }^{3} \mathrm{H}\right] \mathrm{E}_{1}$, and subject III-4 was given $6.39 \mu \mathrm{Ci}\left[{ }^{14} \mathrm{C}\right] \mathrm{A}$ and $3.45 \mu \mathrm{Ci}\left[{ }^{3} \mathrm{H}\right] \mathrm{E}_{1}$. In the latter two studies, the radiolabeled steroids were dissolved in $100 \mathrm{ml}$ of ethanol $(6 \%)$ in normal saline and were infused intravenously over $20 \mathrm{~min}$. In each study, urine was collected for $72 \mathrm{~h}$ after commencement of the infusion of radiolabeled steroids. The $[\rho]_{\mathrm{BU}}{ }^{\mathrm{AE} 1}$ and $\mathrm{PR}-\mathrm{E}_{1}$ were computed from the ${ }^{3} \mathrm{H} /{ }^{14} \mathrm{C}$ ratio and the specific activity of $\mathrm{E}_{1}$ isolated from urine after hydrolysis of glucuronosides with $\beta$-glucuronidase as previously described $(6,8)$.

Production rate of estradiol $\left(P R-E_{2}\right)$ and the transfer constant of conversion of $[\rho]_{B U}{ }^{T E 2}$. This study was conducted only in subject III-3 at the time when he was $12-2 / 12$ yr old. The radiolabeled tracers, 9.45 $\mu \mathrm{Ci}\left[{ }^{14} \mathrm{C}\right] \mathrm{T}$ and $2.21 \mu \mathrm{Ci}\left[{ }^{3} \mathrm{H}\right] \mathrm{E}_{2}$, were dissolved in $55 \mathrm{ml}$ of ethanol (6\%) in normal saline. $10 \mathrm{ml}$ of this solution was delivered intravenously as a bolus and $45 \mathrm{ml}$ was delivered intravenously at a constant rate of infusion for $10 \mathrm{~h}$ by a Harvard pump. Urine was collected for $72 \mathrm{~h}$. The $[\rho]_{\mathrm{BU}}{ }^{\mathrm{TE} 2}$ and PR-E $\mathrm{E}_{2}$ were computed from the ${ }^{3} \mathrm{H} /{ }^{14} \mathrm{C}$ ratio and the specific activity of $E_{2}$ isolated from urine after hydrolysis of glucuronosides with $\beta$-glucuronidase $(6,8)$.

Transfer constant of conversion of plasma $E_{1}$ to $[\rho]_{B U}^{E I E 2}$, and the transfer constant of conversion of plasma $E_{2}$ to $E_{1}[\rho]_{B U} E I E 2$. Subject III-3 was studied when he was $12-3 / 12$ yr old. At this time, $1.57 \mu \mathrm{Ci}$ $\left[{ }^{14} \mathrm{C}\right] \mathrm{E}_{2}$ and $8.18 \mu \mathrm{Ci}\left[{ }^{3} \mathrm{H}\right] \mathrm{E}_{1}$ were dissolved in $57 \mathrm{ml}$ of ethanol $(6 \%)$ in normal saline. $10 \mathrm{ml}$ of this solution was injected intravenously as a bolus and $47 \mathrm{ml}$ was infused at a constant rate for $10 \mathrm{~h}$ by use of a Harvard pump. Urine was collected for $72 \mathrm{~h}$. The $[\rho]_{\mathrm{BU}}{ }^{\mathrm{E} 2 \mathrm{E} 1}$ and the $[\rho]_{\mathrm{BU}}{ }^{\mathrm{E}}{ }^{2} 2$ were computed from the ${ }^{3} \mathrm{H} /{ }^{14} \mathrm{C}$ ratio of $\mathrm{E}_{1}$ and $\mathrm{E}_{2}$ isolated

Table II. Sequential Hormonal Evaluation of Subjects with Familial Gynecomastia

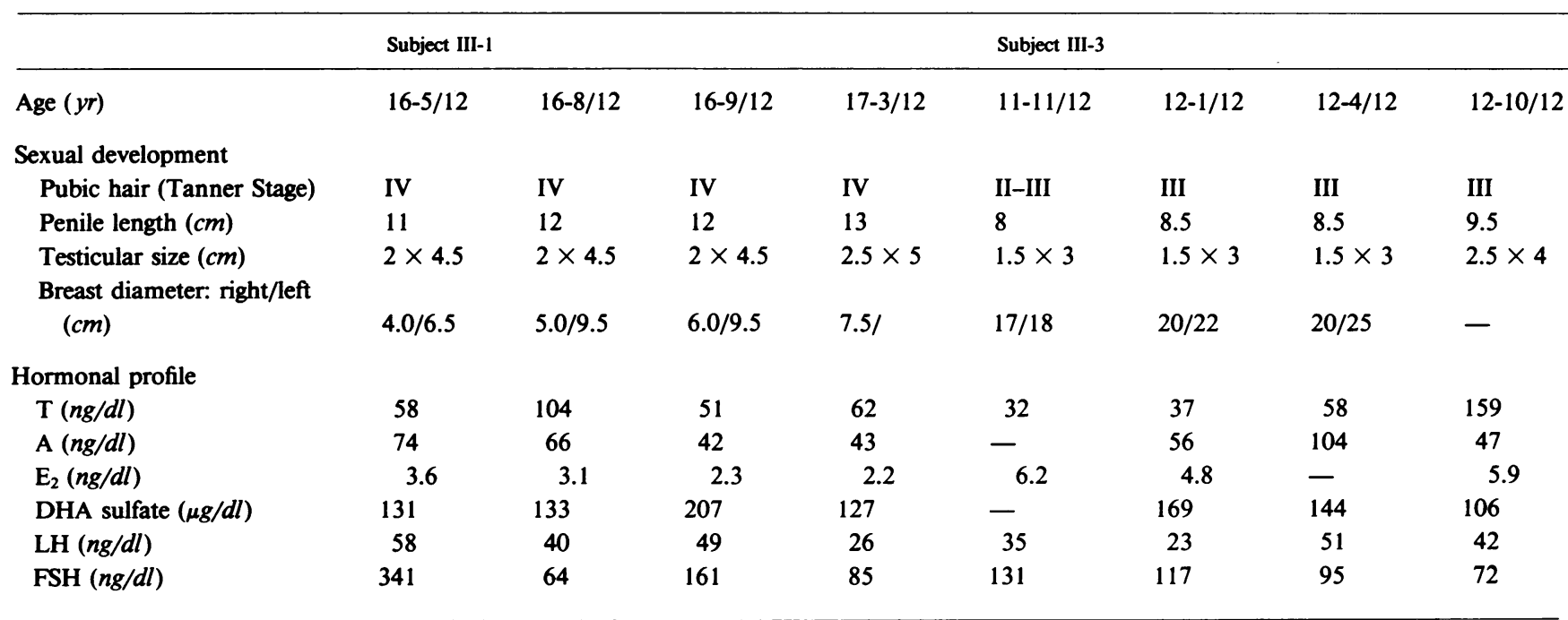


from urine after hydrolysis of glucuronosides with $\beta$-glucuronidase $(6,8)$.

Circadian variation in the levels of plasma $T$ and $A$ and of serum LH and FSH. Subjects III-1 and III-3 were admitted to the Pediatric Clinical Research Unit (The Johns Hopkins Hospital and School of Medicine) when they were $17-3 / 12$ and $12-10 / 12$ yr old, respectively. Beginning at 12:00 noon on the day of admission, blood was collected every $3 \mathrm{~h}$ for the determination of the levels of plasma $\mathrm{T}$ and $\mathrm{A}$, and serum LH and FSH.

Thyrotropin-releasing hormone (TRH) stimulation test and luteinizing hormone-releasing hormone (LHRH) stimulation test. Pituitary function tests were conducted in subjects III-1 and III-3. TRH (500 $\mu \mathrm{g}$ ) was given as a bolus intravenously and thereafter blood samples were collected at $0,15,30,45$, and $60 \mathrm{~min}$ for the determination of thyroid-stimulating hormone (TSH) and prolactin. LHRH $(100 \mu \mathrm{g})$ was given intravenously as a constant infusion for $3 \mathrm{~h}$. Blood samples were obtained at $-60,-30,0,30,60,90,120,150$, and $180 \mathrm{~min}$ for the determination of $\mathrm{LH}$ and FSH.

Human chorionic gonadotropin (hCG) stimulation test. Leydig cell function was evaluated in subjects III-1 and III-3. All blood samples were collected at 9:00 a.m. on the appropriate day when the subjects were $17-3 / 12$ and $12-10 / 12$ yr old, respectively. Base-line blood samples were obtained for the determination of plasma levels of $T, A$, and $E_{2}$. hCG was given at a dose of $5,000 \mathrm{IU} / \mathrm{d}$ intramuscularly for $5 \mathrm{~d}$. On the sixth day after commencing hCG treatment, blood was withdrawn for the determination of the plasma levels of $T, A, E_{2}$, dehydroepiandrosterone (DHA), DHA-sulfate, 17-hydroxyprogesterone (17-OHP), and progesterone $(\mathrm{P})$.

Routine radioimmunoassays (RIA[s]). Assays for serum $\mathrm{LH}$ and FSH (9), plasma T and A (10), 17-OHP, P, and DHA (11) were conducted as described previously. Plasma DHA-sulfate was assayed by use of the Radioscience Laboratories (Carson, CA) RIA kit. $\mathrm{E}_{2}$ was determined by Smith-Kline Clinical Laboratories (King of Prussia, PA) as previously described (12). Serum prolactin was determined by use of the Abbot Laboratories (Chicago, IL) prolactin RIA kit.

\section{Results}

The PR-E $E_{1}$ and $[\rho]_{B U}{ }^{A E I}$ (Table III). The $[\rho]_{\mathrm{BU}}{ }^{\mathrm{AE} 1}$ was similar in the three siblings; the values were $0.16,0.16$, and 0.17 . These values are $\sim 10$ times those found in normal adult men (13) and 15 times those found in two normal prepubertal boys (6). The PR-E $E_{1}$ in subjects III-1, III-3, and III-4 were $65 \mu \mathrm{g}$, $216 \mu \mathrm{g}$, and $23 \mu \mathrm{g} / \mathrm{d}$, respectively. For comparison, the mean PR-E $E_{1}$ of four normal adult men was $58 \mu \mathrm{g} / \mathrm{d}$ with a range of $48-65 \mu \mathrm{g} / \mathrm{d}(13)$, and that of a normal 8 -yr-old boy was 24 $\mu \mathrm{g} / \mathrm{d}(6)$

The PR-E $E_{2}$ and $[\rho]_{B U}{ }^{T E 2}$ (Table III). The $[\rho]_{\mathrm{BU}}{ }^{\mathrm{TE} 2}$, determined in subject III-3, was 0.03 . This value is $\sim 8-10$-fold

Table III. Transfer Constants of Conversion of Plasma $C_{19}$-Steroids to Estrogens and Urinary Production Rate of Estrogens in Sibs with Familial Gynecomastia

\begin{tabular}{lcccc}
\hline Subject & III-1 & III-3 & III-4 & $\begin{array}{l}\text { Normal } \\
\text { adult men }\end{array}$ \\
\hline Age $(y r)$ & 16 & 12 & 11 & $26-35$ \\
{$[\rho]_{\mathrm{BU}}{ }_{\mathrm{AE1}}$} & 0.16 & 0.16 & 0.17 & 0.016 \\
$\mathrm{PR}_{1}(\mu \mathrm{g} / 24 \mathrm{~h})$ & 65 & 216 & 23 & 58 \\
{$[\rho]_{\mathrm{BU}}{ }^{\mathrm{TE2}}$} & - & 0.03 & - & 0.0037 \\
$\mathrm{PR}_{2}(\mu \mathrm{g} / 24 \mathrm{~h})$ & - & 150 & - & 44 \\
{$[\rho]_{\mathrm{BU}}{ }^{\mathrm{EIE2}}$} & - & 0.47 & - & 0.53 \\
{$[\rho]_{\mathrm{BU}}{ }^{\text {E2E1 }}$} & - & 0.97 & - & 0.93 \\
\hline
\end{tabular}

greater than the fractional conversion of $T$ to $E_{2}$ previously determined by MacDonald et al. (13) in four normal adult men (range: $0.0028-0.004$; mean value $=0.0037$ ). The production rate of $E_{2}$ in this subject was $150 \mu \mathrm{g} / \mathrm{d}$, a value that is severalfold greater than the value of $44 \mu \mathrm{g} / \mathrm{d}$ (range: $35-47 \mu \mathrm{g} /$ d) for normal adult men (13). The ${ }^{3} \mathrm{H} /{ }^{14} \mathrm{C}$ ratios of urinary $\mathrm{E}_{1}$ and $E_{2}$ were the same after the infusion of $\left[{ }^{3} \mathrm{H}\right] E_{2}$ and $\left[{ }^{14} \mathrm{C}\right] \mathrm{T}$, which suggested that $E_{2}$ was the principal product of the aromatization of $\mathrm{T}$.

$[\rho]_{B U}^{E I E 2}$ and $[\rho]_{B U}^{E 2 E 1}$ (Table III). The $[\rho]_{\mathrm{BU}}{ }^{E 1 E 2}$ in subject III-3 was 0.49 and the $[\rho]_{\mathrm{BU}}{ }^{\mathrm{E} 2 \mathrm{E} 1}$ in this subject was 0.97 . These values are similar to those found by MacDonald et al. (13) for normal men (mean $=0.49$; range: $0.44-0.53$ for $[\rho]_{\mathrm{BU}}{ }^{\mathrm{EIE} 2}$, mean $=0.93$; range: $0.90-0.97$ for $[\rho]_{\mathrm{BU}}^{\mathrm{E2E1}}$ ).

Circadian variation of plasma hormones. Because the levels of plasma $\mathrm{T}$ were lower than expected for the respective Tanner stage of pubertal development in subjects III-1, III-3, and III-4 at the time of initial evaluation (Table I), and because the levels of plasma $T$ and $A$ remained low during the course of a year of observation (Table II), the circadian variation in plasma $\mathrm{T}$ and $\mathrm{A}$, and serum $\mathrm{LH}$ and $\mathrm{FSH}$, was investigated in subjects III-1 and III-3. A diurnal variation in $\mathrm{T}$ and $\mathrm{A}$ was observed (Fig. 3).

LHRH stimulation and TRH stimulation tests. Pituitary function tests were conducted in subjects III-1 and III-3 when they were $17-3 / 12$ and 12-10/12 yr old, respectively. After LHRH administration, serum LH rose from a base-line level of $29 \mathrm{ng} / \mathrm{ml}$ to a maximum value of $142 \mathrm{ng} / \mathrm{ml}$ at $180 \mathrm{~min}$ in subject III- 1 and from $28 \mathrm{ng} / \mathrm{ml}$ to $170 \mathrm{ng} / \mathrm{ml}$ in subject III-3. These results are in the normal range (14). After TRH administration, the peak serum level of TSH (subject III- $1=19.0$ $\mu \mathrm{IU} / \mathrm{ml}$; subject III-3 $=16.0 \mu \mathrm{IU} / \mathrm{ml}$ ) and the peak serum level of prolactin (subject III-1 $=40 \mathrm{ng} / \mathrm{ml}$; subject III-3 $=41 \mathrm{ng}$ / $\mathrm{ml})$ were normal $(15,16)$.

hCG stimulation test. The results of the hCG stimulation tests conducted in subjects III-1 and III-3 are given in Table IV. The plasma $E_{2}$ levels were disproportionately elevated compared with those of plasma $\mathrm{T}$ in both the base-line and the post hCG-treatment samples (17). In addition, there was no abnormal accumulation of plasma DHA, P, 17-OHP, or A after hCG stimulation (data not shown).

\section{Discussion}

In 1977, Hemsell et al. (6) described the findings in a prepubertal boy who developed gynecomastia. Breast development in this
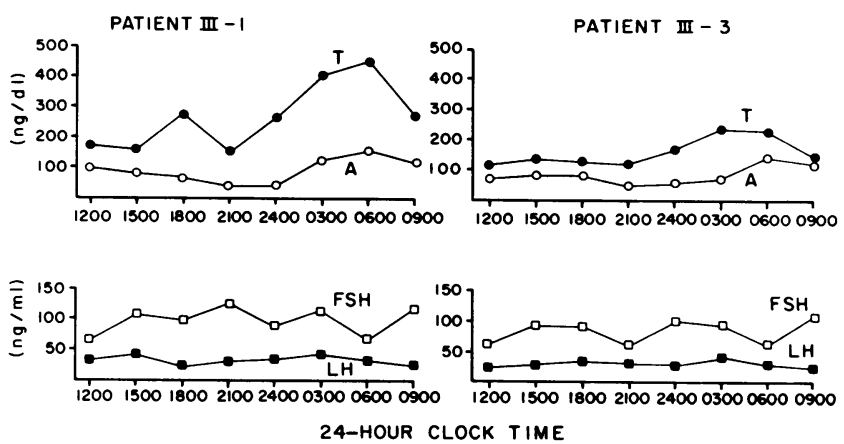

Figure 3. Circadian variation of plasma T, A, serum FSH, and LH in two siblings with familial gynecomastia. 
Table IV. 5-D hCG Stimulation Test in

Two Sibs with Familial Gynecomastia

\begin{tabular}{llcc}
\hline Subjects (age) & Steroid & Pretreatment & After hCG \\
\hline & ng/dl & & \\
III-3 (13 yr) & T & 148 & 1,565 \\
& A & 119 & 136 \\
& E $_{2}$ & 6.5 & 23.8 \\
III-1 (17 yr) & T & 265 & 2,725 \\
& A & 120 & 189 \\
& E $_{2}$ & 9.4 & 27.9 \\
\hline
\end{tabular}

subject began at $8-7 / 12$ yr of age and progressed slowly. The rate of linear growth after the appearance of gynecomastia was accelerated and the bone age was advanced appreciably. Pubic hair was noted first at $10-5 / 12$ yr and levels of plasma $T$ ranged between 270 and $410 \mathrm{ng} / \mathrm{dl}$ from $12-6 / 12$ to $13 \mathrm{yr}$. A persistent elevation in plasma levels of $E_{1}$ and $E_{2}$ also was demonstrated. After excluding an adrenal or testicular source of excess estrogen secretion, the elevated estrogen levels were shown to be due to an increase in the peripheral conversion of plasma $\mathrm{C}_{19}$-steroids to estrogens. The fractional conversions of plasma $A$ to $E_{1}$ and of plasma $T$ to $E_{2}$ were 50 times those found in normal young men. In addition, $94 \%$ of the extraglandular aromatization occurred in extrahepatic sites. Furthermore, the $E_{1}$ produced in peripheral tissue from the aromatization of $A$ underwent extensive sulfurylation in the tissue site(s) of aromatization before its release into blood (6).

A number of similarities exist between the subjects of the present study and the subject described by Hemsell et al. The five affected family members in our study developed gynecomastia at an early age (10-11 yr), starting concomitantly with the sexual maturational processes of male puberty. This sequence is in contrast to that of the physiologic pubertal gynecomastia that usually begins $\sim 6-12$ mo after the appearance of pubic hair. In addition, despite the relatively early appearance of physical changes, presumed to be due to adrenarche, pubertal development progressed slowly in the subjects with gynecomastia in this study. $2 \mathrm{yr}$ after the appearance of pubic hair in subject III-3, the levels of plasma $T$ still were quite low. The low levels of plasma $T$ in subject III-1 when he was $17 \mathrm{yr}$ of age are also striking considering that pubertal development had commenced at $11 \mathrm{yr}$ of age. In comparison to males with physiologic gynecomastia and Tanner Stage IIIIV pubertal development, where a $T / E_{2}$ ratio of $140: 1(\mathrm{ng} / \mathrm{dl}$ : $\mathrm{ng} / \mathrm{dl}$ ) has been reported (1), there was a disproportionate elevation of plasma $E_{2}$ levels compared with those of plasma $T$ in our subjects, the $T / E_{2}$ ratios being $16: 1$ in subject III-1 and 5:1 in subject III-3. Known causes of gynecomastia were excluded on the basis of a normal 46,XY karyotype, normal or low levels of serum gonadotropins and prolactin, normal serum levels of thyroxine, and normal liver function tests. A scan (CT) of the adrenal glands in subject III-3 was normal.

The fractional conversion of $[\rho]_{\mathrm{BU}}{ }^{\mathrm{AEI}}$ in subjects III-1, III3 , and III-4 was 10 times that found in normal young adult men, and 15 times that of prepubertal boys. PR- $E_{1}$ in the proband (III-3) was markedly elevated $(216 \mu \mathrm{g} / \mathrm{d})$, whereas in his older brother (III-1) it was $65 \mu \mathrm{g} / \mathrm{d}$, which was well within the range for normal adult men (13). Unfortunately, the production rates of $\mathrm{A}$ were not determined, and therefore we cannot determine the rate of production of $E_{1}$ from the conversion of $A$ to $E_{1}$. In fact, the variation in the plasma levels of A from day to day (Table II) and within a 24-h period (Fig. 2) would have made it impossible to estimate accurately the production rate of $\mathrm{A}$. One possible explanation for the difference in PR- $E_{1}$ in subjects III-1 and III-3 might be that the production rate of $A$ in subject III-3 was greater because of obesity (18). Although the PR- $E_{1}$ in subject III-1 was in the normal adult range, it was higher than expected for a pubertal boy. The presence of mild gynecomastia was consistent with this moderate increase in PR-E $\mathrm{E}_{1}$.

The PR-E $E_{1}$ of subject III-4 at 11-1/12 yr was normal for a prepubertal boy, although the fractional conversion of $A_{\gamma}$ to $E_{1}$ in this subject was elevated. At that time, there were a few strands of pubic hair but the genitalia of this boy were otherwise entirely prepubertal, as were the plasma levels of $T$, $\mathrm{E}_{2}, \mathrm{LH}$, and $\mathrm{FSH}$. We assume that the production rate of $\mathrm{A}$ was variable during the early stage of his adrenarche, and that the gynecomastia resulted from intermittent exposure to estrogen arising from the extraglandular conversion of adrenal $A$ to $\mathrm{E}_{1}$.

The ${ }^{3} \mathrm{H} /{ }^{14} \mathrm{C}$ ratios of urinary $\mathrm{E}_{1}$ and $\mathrm{E}_{2}$ were the same after the infusion of $\left[{ }^{3} \mathrm{H}\right] \mathrm{E}_{1}$ and $\left[{ }^{14} \mathrm{C}\right] \mathrm{A}$, which indicated that estrone (or possibly estrone-sulfate) was the product of aromatization of plasma $\mathrm{A}$.

The fractional conversion of $T$ to $E_{2}$ in subject III-3 was eight times that found in normal adult men. The urinary production rate of $E_{2}, 150 \mu \mathrm{g} / 24 \mathrm{~h}$, was above the normal range. It should be stressed that $[\rho]_{\mathrm{BU}}{ }^{\mathrm{TE} 2}$ and $[\rho]_{\mathrm{BU}}{ }^{\mathrm{AE} 1}$ represent the sum of all routes of conversion of $T$ to $E_{2}$ and of $A$ to $E_{1}$, respectively. $E_{2}$ can arise from $T$ by direct conversion or indirectly by the pathway $T \rightarrow A \rightarrow E_{1} \rightarrow E_{2}$. Similarly, $E_{1}$ can arise from $A$ by direct conversion or indirectly by the pathway $\mathrm{A} \rightarrow \mathrm{T} \rightarrow \mathrm{E}_{2} \rightarrow \mathrm{E}_{1}$.

After determining that the estrogen imbalance observed in the subject of this study was due to increased extraglandular aromatization, we speculated as to whether $E_{2}$ in increased amounts might act to diminish the release of $\mathrm{LH}$, and therefore diminish testosterone production. We also sought to ascertain whether the increased $E_{2}$ levels might act to directly inhibit the production of $\mathrm{T}$ by Leydig cells.

Although we could not assess directly the effects of elevated estrogen production on the release of LH by the pituitary, we gathered data that is suggestive that the function of the hypothalamic-pituitary axis was normal in these subjects. It is known that in normal pubertal boys, there is a marked diurnal variation in levels of plasma $T$, with peak values occurring at night, $\sim 4-8 \mathrm{~h}$ after the onset of sleep $(19,20)$. The magnitude of the diurnal variation in plasma $T$ decreases gradually as puberty progresses until the level of plasma $T$ is similar throughout the day. Large and Anderson (2) found the same diurnal variation for plasma $\mathrm{T}$ levels in boys with gynecomastia and in boys in whom there was a physiologic delay in the onset of puberty. As presented in Fig. 2, the diurnal variation in plasma $T$ was normal in subjects III-1 and III-3, which suggested that the normal rhythmicity in LH release was preserved. The marked diurnal variation in plasma $T$ in our subjects also may provide an explanation for the apparent discrepancy between the degree of sexual development observed and the low levels of plasma $T$ obtained at the time of regular clinic visits. Additional evidence in support of normal pituitary 
function in the subjects of this study was obtained by the finding of a normal response in serum LH to LHRH treatment (14) and a normal response in serum prolactin after the infusion of TRH (16).

With regard to Leydig cell function in these subjects, by hCG stimulation we found that the Leydig cells were capable of producing testosterone in normal amounts in spite of elevated levels of $E_{2}$. This is in contrast to some findings in men (21) and in experimental animals (22) that are suggestive that $E_{2}$ acts directly to inhibit the secretion of $T$ by Leydig cells. These studies, however, do not rule out a possible defect in $T$ secretion in our patients, since base-line levels of plasma $T$ were low for Tanner Stage in these subjects. Unfortunately, we do not have information about sperm production in the subjects of this study and we cannot predict the effect of the increased extraglandular aromatase activity on fertility.

We also studied the response of plasma levels of $E_{2}$ to hCG administration. In these studies, hCG was administered intramuscularly in a daily dose of $3,000 \mathrm{U} / \mathrm{M}^{2}$ of body surface area, with a maximum of $5,000 \mathrm{U}$, for $5 \mathrm{~d}$. By use of this regimen in a group of normal adult men, the mean level of plasma $\mathrm{T}$ rose from $612 \mathrm{ng} / \mathrm{dl}$ to $1,404 \mathrm{ng} / \mathrm{dl}$ (unpublished data). By use of a similar regimen in a group of normal men, Weinstein et al. (16) found that plasma $T$ rose from 770 to $1750 \mathrm{ng} / \mathrm{dl}$, and that the mean level of plasma $E_{2}$ rose from 3.0 to $10.4 \mathrm{ng} / \mathrm{dl}$. In our subjects (III-1 and III-3), the increase in plasma $T$ after hCG was normal. The rise in plasma $E_{2}$ levels after hCG stimulation, however, was three times greater than that observed in normal men, which suggested again that in these subjects there was increased extraglandular aromatase activity.

We have presented evidence that in several men of a single family, there was increased extraglandular aromatase activity compared with that found in normal men. Several possibilities exist to explain this abnormality. The defect could be due to a gene mutation resulting in an enzyme complex with increased activity, or to an increase in the intracellular concentration of enzyme due to increased production or decreased catabolism of the enzyme.

Hemsell et al. (6) proposed that the increased extraglandular aromatization was due to a persistence of fetal levels of both aromatase and sulfokinase enzyme activities. In view of the difference in the level of peripheral aromatase activity observed in our subjects ( 10 times normal), compared with the activity in the subject described by Hemsell et al. (50 times normal), it is possible that one is dealing with different underlying defects in the two families. It is of interest that George et al. (23) demonstrated that the increased estrogen formation in the Sebright Bantam chicken is due to an abnormal elevation in the level of peripheral aromatase activity.

Aromatase activity is widely distributed in several extraglandular tissues including skin, fat, muscle, kidney, bone, and certain areas of the central nervous system. We could not determine whether the abnormality in our patients resides in one tissue alone or whether the defect is present in all tissues. Hemsell et al. (6) reported that $<6 \%$ of the aromatization observed in their subject occurred in intrahepatic sites. This is consistent with the recent observation that aromatase activity in liver accounts for only a minimal fraction of the extraglandular aromatization in normal adult men (24).

The affected members of the family of this study include three siblings, a maternal cousin, and a maternal uncle. We found increased fractional conversion of androstenedione and testosterone to estrogens in the three siblings, but we have not studied the affected maternal uncle and maternal cousin. Both the history and the hormonal profile of the uncle and cousin are suggestive that in these men there also is excessive extraglandular aromatase activity. The pattern of inheritance of this disorder in the family studied is suggestive of an X-linked recessive or a sex-limited autosomal dominant trait. Further studies will be necessary to elucidate the underlying molecular and genetic defects in affected persons.

\section{Acknowledgments}

We thank Mr. Frank Herford for expert technical assistance and Diane Ogorzalek for secretarial assistance.

This work was supported in part by U. S. Public Health Service research grants AM-00180-32 and 5-P01-AG00306; by National Institutes of Health General Clinical Research Centers grants for pediatrics (M01-RR-00052-21) and medicine (M01-RR-00035-22); by Research Career Development Award 5-K06-AM-21855 (Dr. Migeon); and by General Clinical Research Centers (Clinical Associate Physician) (3M01-RR-0052) (Dr. Berkovitz).

\section{References}

1. Lee, P. A. 1975. The relationship of concentrations of serum hormones to pubertal gynecomastia. J. Pediatr. 86:212-215.

2. Large, D. M., and P. C. Anderson. 1979. Twenty four hour profiles of circulating androgens and oestrogens in male puberty with and without gynecomastia. Clin. Endocrinol. (Oxf.). 11:505-521.

3. Marynick, S. P., B. C. Nisula, J. C. Pita, and D. L. Loriaux. 1980. Persistent pubertal macromastia. J. Clin. Endocrinol. Metab. 50: 128-130.

4. Wilson, J. D., J. Aiman, and P. C. MacDonald. 1980. The pathogenesis of gynecomastia. Adv. Intern. Med. 29:1-32.

5. Carlson, H. E. 1980. Gynecomastia. N. Engl. J. Med. 303:795799.

6. Hemsell, D. L., C. D. Edman, J. F. Marks, P. K. Siiteri, and P. C. MacDonald. 1977. Massive extraglandular aromatization of plasma androstenedione resulting in feminization of a prepubertal boy. J. Clin. Invest. 60:455-464.

7. Tanner, J. M. 1962. Growth at adolescence. Oxford, England. Blackwell Scientific Publications. Second ed.

8. Siiteri, P. K. 1963. The isolation of urinary estrogens and determination of the specific activities following the administration of radioactive precursors to humans. Steroids. 2:687-712.

9. Odell, W. D., G. T. Ross, and P. L. Rayford. 1966. Radioimmunoassay for human luteinizing hormone. Metab. Clin. Exp. 15: 287-289.

10. Rivarola, M. A., and C. J. Migeon. 1966. Determination of testosterone and androst-4-ene-3,17-dione concentration in human plasma. Steroids. 7:103-117.

11. Gutai, J. P., W. J. Meyers, A. A. Kowarski, and C. J. Migeon. 1977. Twenty four hour integrated concentrations of progesterone, 17hydroxyprogesterone and cortisol in normal male subjects. J. Clin. Endocrinol. Metab. 44:116-120.

12. Smith, D. E., R. H. Picker, M. Sinosich, and D. M. Saunders. 1980. Assessment of ovulation by ultrasound and estradiol levels during spontaneous and induced cycles. Fertil. Steril. 33:387-390.

13. MacDonald, P. C., J. D. Madden, P. E. Brenner, J. D. Wilson, and P. K. Siiteri. 1979. Origin of estrogen in normal men and women with testicular feminization. J. Clin. Endocrinol. Metab. 49:905-916.

14. Reiter, E. O., A. W. Root, and G. E. Duckett. 1976. The response of pituitary gonadotropes to a constant infusion of luteinizing hormone-releasing hormone (LHRH) in normal prepubertal and pubertal children and in children with abnormalities of sexual development. J. Clin. Endocrinol. Metab. 43:400-411. 
15. Foley, T. P., Jr., L. S. Jacobs, W. Hoffman, W. H. Daughaday, and R. M. Blizzard. 1972. Human prolactin and thyrotropin concentrations in the serums of normal and hypopituitary children before and after the administration of synthetic thyrotropin-releasing hormone. J. Clin. Invest. 51:2143-2150.

16. Spitz, I. M., H. J. Hirsch, and S. Trestian. 1983. The prolactin response to thyrotropin-releasing hormone differentiates isolated gonadotropin deficiency from delayed puberty. N. Engl. J. Med. 308 575-579.

17. Weinstein, R. L., R. P. Kelch, M. R. Jenner, S. L. Kaplan, and M. M. Grumbach. 1974. Secretion of unconjugated androgens and estrogens by the normal and abnormal human testis before and after human chorionic gonadotropin. J. Clin. Invest. 53:1-6.

18. Kirschner, M. A., G. Schneider, N. H. Ertel, and E. Worte. 1982. Obesity, androgens, estrogens, and cancer risk. Cancer Res. 42(Suppl.):3281s-3282s.

19. Judd, H. L., D. C. Parker, T. M. Siler, and S. C. C. Yen. 1974. The nocturnal rise of plasma testosterone in pubertal boys. J. Clin. Endocrinol. Metab. 38:710-713.
20. Parker, D. C., H. L. Judd, L. G. Rossman, and S. C. C. Yen. 1975. Pubertal sleep-wake patterns of episodic LH, FSH and testosterone release in twin boys. J. Clin. Endocrinol. Metab. 40:1099-1109.

21. Forest, M. G., A. LeCoq, and J. M. Saez. 1979. Kinetics of human chorionic gonadotropin-induced steroidogenic response of the human testis. II. Plasma $17 \alpha$-hydroxyprogesterone, $\Delta^{4}$-androstenedione, estrone and estradiol-17 $\beta$ : evidence for the action of human chorionic gonadotropin on intermediate enzymes implicated in steroid biosynthesis. J. Clin. Endocrinol. Metab. 49:284-291.

22. Catt, K. J., J. P. Harwood, R. N. Clayron, T. F. Davies, V. Chan, M. Katikineni, J. Nozu, and M. L. Dufan. 1980. Regulation of peptide hormone receptors and gonadal steroidogenesis. Recent Prog. Horm. Res. 36:557-622.

23. George, F. W., and J. D. Wilson. 1980. Pathogenesis of the Henny Feathering trait in the Sebright Bantam chicken. J. Clin. Invest. 66:57-65.

24. Longcope, C., K. Sato, C. McKay, and R. Horton. 1984. Aromatization splanchnic tissue in men. J. Clin. Endocrinol. Metab. 58:1089-1093. 